\title{
Using Selective Drainage Methods to Extract Continuous Surface Flow from 1-Meter Lidar-Derived Digital Elevation Data
}

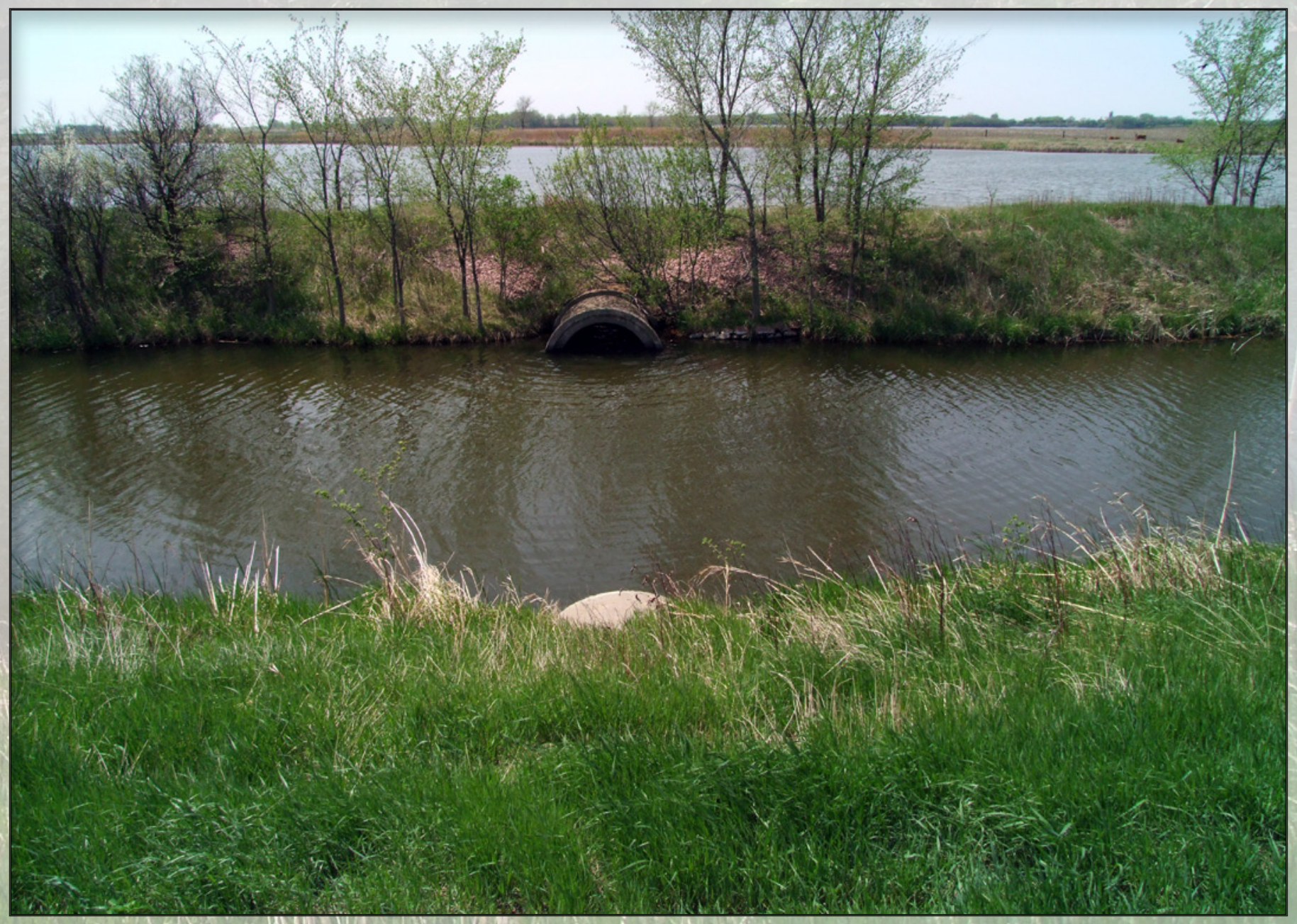

Scientific Investigations Report 2010-5059 
Cover photograph. A water body located in Minnehaha County, 2009. Photograph taken by Jason M. Stoker, Physical Scientist, U.S. Geological Survey. 


\section{Using Selective Drainage Methods to Extract Continuous Surface Flow from 1-Meter Lidar-Derived Digital Elevation Data}

By Sandra K. Poppenga, Bruce B. Worstell, Jason M. Stoker, and Susan K. Greenlee

Scientific Investigations Report 2010-5059 


\title{
U.S. Department of the Interior \\ KEN SALAZAR, Secretary \\ U.S. Geological Survey \\ Marcia K. McNutt, Director
}

\section{U.S. Geological Survey, Reston, Virginia: 2010}

\author{
For more information on the USGS — the Federal source for science about the Earth, its natural and living resources, \\ natural hazards, and the environment, visit http://www.usgs.gov or call 1-888-ASK-USGS \\ For an overview of USGS information products, including maps, imagery, and publications, \\ visit http://www.usgs.gov/pubprod \\ To order this and other USGS information products, visit http://store.usgs.gov
}

Any use of trade, product, or firm names is for descriptive purposes only and does not imply endorsement by the U.S. Government.

Although this report is in the public domain, permission must be secured from the individual copyright owners to reproduce any copyrighted materials contained within this report.

Suggested citation:

Poppenga, S.K., Worstell, B.B., Stoker, J.M., and Greenlee, S.K., 2010, Using selective drainage methods to extract continuous surface flow from 1-meter lidar-derived digital elevation data: U.S. Geological Survey Scientific Investigations Report 2010-5059, 12 p. 


\section{Contents}

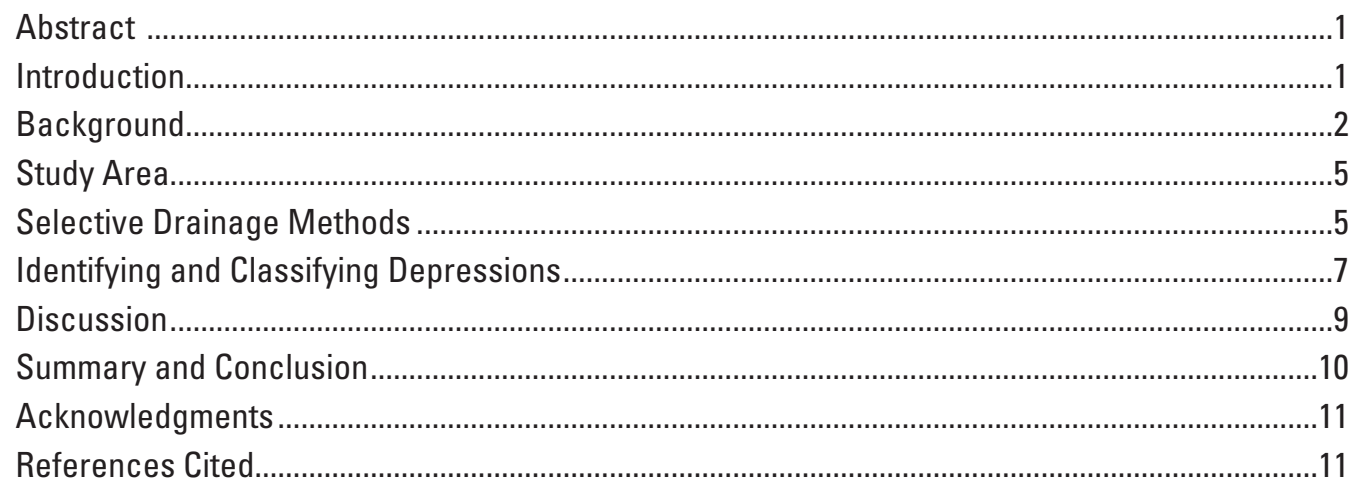

\section{Figures}

1-3. Maps showing:

1. Lidar-derived surface flow before $(A)$ and after $(B)$ selective draining of a difference grid depression that is overlain on aerial imagery of Minnehaha County,

South Dakota.

2. Lidar-derived surface flow before (A) and after (B) selective draining of a difference grid depression that is overlain on 1-meter lidar-derived elevation data in Minnehaha County, South Dakota

3. Research area located in the U.S. Geological Survey Sioux Falls West Quadrangle N4330 — W9645/7.5 overlain on 1-meter lidar-derived elevation data in Minnehaha County, South Dakota

4. Flow chart showing selective drainage methods showing (A) filling process to create a depressionless DEM, $(B)$ contributing area threshold processes that results in obstructed lidar-derived surface flow, and (C) selective drainage methods that drains surface flow through obstructions to create a fully connected drainage network.

5-7. Maps showing:

5. Closed drainage basins identified as Sioux Quartzite mines that do not contribute to downstream flow with $(A)$ the difference grid depression depth at the deepest cell is 64.1578 meters, and (B) aerial imagery of the Sioux Quartzite mines

6. The tinning of water surfaces in the 1-meter lidar-derived elevation data

7. Water bodies extracted from the absence of lidar returns over water surfaces in 1-meter lidar point cloud data overlain on aerial imagery of Minnehaha County, South Dakota. 


\section{Conversion Factors and Datums}

\begin{tabular}{lcl}
\hline Multiply & By & To obtain \\
\hline \multicolumn{2}{c}{ Lentimeter $(\mathrm{cm})$} & \multicolumn{2}{l}{ Length } \\
meter $(\mathrm{m})$ & 3.3937 & inch (in.) \\
meter $(\mathrm{m})$ & 1.094 & foot $(\mathrm{ft})$ \\
square meter $\left(\mathrm{m}^{2}\right)$ & 10.76 & yard (yd) \\
\hline
\end{tabular}

Vertical coordinate information is referenced to the North American Vertical Datum of 1988 (NAVD 88).

Horizontal coordinate information is referenced to the North American Datum of 1983 (NAD 83). 


\title{
Using Selective Drainage Methods to Extract Continuous Surface Flow from 1-Meter Lidar-Derived Digital Elevation Data
}

\author{
By Sandra K. Poppenga ${ }^{1}$, Bruce B. Worstell ${ }^{2}$, Jason M. Stoker ${ }^{1}$, and Susan K. Greenlee ${ }^{1}$
}

\section{Abstract}

Digital elevation data commonly are used to extract surface flow features. One source for high-resolution elevation data is light detection and ranging (lidar). Lidar can capture a vast amount of topographic detail because of its fine-scale ability to digitally capture the surface of the earth. Because elevation is a key factor in extracting surface flow features, high-resolution lidar-derived digital elevation models (DEMs) provide the detail needed to consistently integrate hydrography with elevation, land cover, structures, and other geospatial features. The U.S. Geological Survey has developed selective drainage methods to extract continuous surface flow from high-resolution lidar-derived digital elevation data. The lidarderived continuous surface flow network contains valuable information for water resource management involving flood hazard mapping, flood inundation, and coastal erosion.

DEMs used in hydrologic applications typically are processed to remove depressions by filling them. High-resolution DEMs derived from lidar can capture much more detail of the land surface than courser elevation data. Therefore, high-resolution DEMs contain more depressions because of obstructions such as roads, railroads, and other elevated structures. The filling of these depressions can significantly affect the DEM-derived surface flow routing and terrain characteristics in an adverse way. In this report, selective draining methods that modify the elevation surface to drain a depression through an obstruction are presented. If such obstructions are not removed from the elevation data, the filling of depressions to create continuous surface flow can cause the flow to spill over an obstruction in the wrong location. Using this modified elevation surface improves the quality of derived surface flow and retains more of the true surface characteristics by correcting large filled depressions.

\footnotetext{
${ }^{1}$ U.S. Geological Survey.

${ }^{2}$ Stinger Ghaffarian Technologies (SGT), Inc., contractor to the U.S. Geological Survey Earth Resources Observation and Science (EROS) Center. Work performed under USGS contract 08HQCN0005.
}

A reliable flow surface is necessary for deriving a consistently connected drainage network, which is important in understanding surface water movement and developing applications for surface water runoff, flood inundation, and erosion. Improved methods are needed to extract continuous surface flow features from high-resolution elevation data based on lidar.

\section{Introduction}

There is an increasing demand for continuous surface flow features extracted from lidar-derived bare earth elevation data (Stoker and others, 2008; Kenny and others, 2008; Liu and others, 2005; Snyder, 2009). Because topography is an important factor in deriving hydrologic features, the vertical accuracy and high-resolution characteristics of lidar-derived elevation greatly improve the quality of extracted hydrologic features, such as surface flow and drainage channels. As the need for flood hazard mapping and emergency response intensifies, continuous surface flow modeling improvements are needed to meet this obligation. Additionally, researchers studying hydrology have determined lidar's bare earth resolving properties, high-resolution, and accuracy to be helpful in improving their understanding of surface water movements, drainage patterns, flood inundation and coastal erosion (Stoker and others, 2008).

Lidar has been increasingly accepted as an effective and accurate technology for acquiring high-resolution elevation data for bare earth, vegetation, and structures (Stoker and others, 2006). Because of lidar's fine-scale ability to represent topography, a vast amount of detail is captured in the bare earth lidar elevation data. Although this detail is desirable for incorporating the best available elevation data into the National Elevation Dataset (NED) (Gesch and others, 2002), extracting continuous surface flow from high-resolution digital elevation models (DEMs) presents some challenges because obstructions, such as elevation data representing bridges or roads, are introduced (Poppenga and others, 2009). 
Using Selective Drainage Methods to Extract Continuous Surface Flow from Digital Elevation Data

Vegetation also may cause problems if the bare earth surface model erroneously contains vegetation return signatures.

Concerns regarding lidar-derived hydrologic modeling that address surface flow obstructions have been presented in the scientific literature (Barber and Shortridge, 2005; Kenny and others, 2008; Wang and Liu, 2006). Barber and Shortridge (2005) state there are limits to the practical use of lidar that vary with the intended application, and that a high-resolution, high-accuracy DEM does not necessarily produce a highly reliable model of surface flow. Other researchers have stated that lidar-derived DEMs gave a detailed delineation of subcatchments and offered the capability of improving the quality of lidar-derived hydrological features (Liu and others, 2005; Snyder, 2009). However, the accuracy of hydrological derivatives (surface flow) is affected by the DEM quality and resolution (Zhang and Montgomery, 1994, Wolock and McCabe, 2000) as well as the type of source data the derivatives are based upon. Moore and others (1991) state that the deficiency of many hydrological and water quality models is their inability to account for the effects of terrain on flow processes.

In response to the need for improved elevation-derived continuous surface flow modeling, this report describes selective drainage methods that are incorporated into a hydrologic conditioning phase where surface flow is drained through obstructions in the lidar-DEM. The selective draining methodology enhances lidar-derived feature extraction by providing an improved representation of continuous surface flow.

\section{Background}

Elevation data are fundamentally important for hydrologic feature extraction and analysis and are being used routinely as a source for deriving hydrologic features such as drainage basins and drainage channel networks (Gesch, 1999; Moore and others, 1993; Band, 1999; Garbrecht and Martz, 2000; Wang and Liu, 2006). Elevation data are critically important for many hydrologic studies (Gesch, 2007) and are useful for deriving parameters that describe the local drainage conditions such as watersheds and stream channels (Gesch, 2005; Poppenga and Worstell, 2008; Kost and Kelly, 2001). Additionally, elevation data are used to extract flow direction, upslope contributing area, aspect, and surface flow features. These parameters are important for many topographically based hydrologic modeling applications.

All hydrologic models ultimately rely on some form of overland flow simulation to define drainage courses and watershed structure (Garbrecht and Martz, 2000). Various methods have been proposed for routing overland flow in the gridded elevation surface. Attempts have been made to remove depressions by smoothing the DEM data (O'Callaghan and Mark, 1984; Mark, 1983). The smoothing approach removes shallow depressions, but deeper depressions remain (Jenson and Domingue, 1988). Duke and others (2003) used a road enforcement algorithm to improve the accuracy of grid-based overland flow routing through the use of ancillary road, ditch, and culvert data. Others have proposed imposing relief across flats (Martz and Garbrecht, 1993, Garbrecht and Martz, 2000), network seeding (Kenny and others, 2001, 2008; Matthews and Kuyvenhoven, 2002), and outlet breaching (Martz and Garbrecht, 1999). The most common methods involve determining for each cell in a raster DEM the flow direction by reference to the elevation of the cell in comparison to its eight adjacent neighbors (Marks and others, 1984; O'Callaghan and Mark, 1984; Band, 1986; Jenson and Domingue, 1988; Jenson, 1991). At present (2010), the contributing area threshold model (Jenson and Domingue, 1988; Jenson, 1991) has been implemented by nearly all geographic information systems (GIS) and hydrologic software packages (Gesch, 1999, 2005; Wang and Liu, 2006), and it uses a method of filling spurious depressions to create a depressionless DEM.

The process of filling depressions in lower resolution elevation data (30-m) to derive surface flow is a common technique; however, the actual filling process causes problems in hydrological modeling (Band, 1999; Hutchinson and Gallant, 1999; Kenny and others, 2008; Wang and Liu, 2006). The identification and classification process for filling depressions creates challenges when attempting to automatically derive fully connected drainage networks. Because bare earth elevation data derived from lidar are complex topographic surfaces, geographic features are more prominent, thereby causing obstructions in the contributing area threshold model (Jenson and Domingue, 1988). In other words, lidar returns capture details of the landscape, such as bridges and roads, which are higher than the surrounding terrain. The lidar returns also capture more detailed depressions that result in impediments to extracting continuous surface flow from lidar-derived DEMs. If the obstructions are removed, a more fully connected drainage network can be derived from a depressionless DEM. The current (2010) practice of the lidar vendor is to remove the lidar points associated with the bridges or culverts for water to travel downstream (Stoker, 2009). However, if the lidar points associated with such obstructions are not removed, the filling of depressions to create continuous surface flow tends to spill the surface flow over the obstruction in the wrong location (figs. 1 and 2) (Poppenga and others, 2009).

Identification of surface flow depressions is a critical step for deriving a fully connected drainage network from high-resolution elevation data. With the growing availability of lidar-derived DEMs, there is a need to develop methods to systematically identify and classify surface flow depressions that form behind flow obstructions. Because of the complexity of high-resolution elevation data, methods are described herein to classify depressions and drain surface flow through obstructions from 1-meter lidar-derived DEMs using selective drainage methods. 

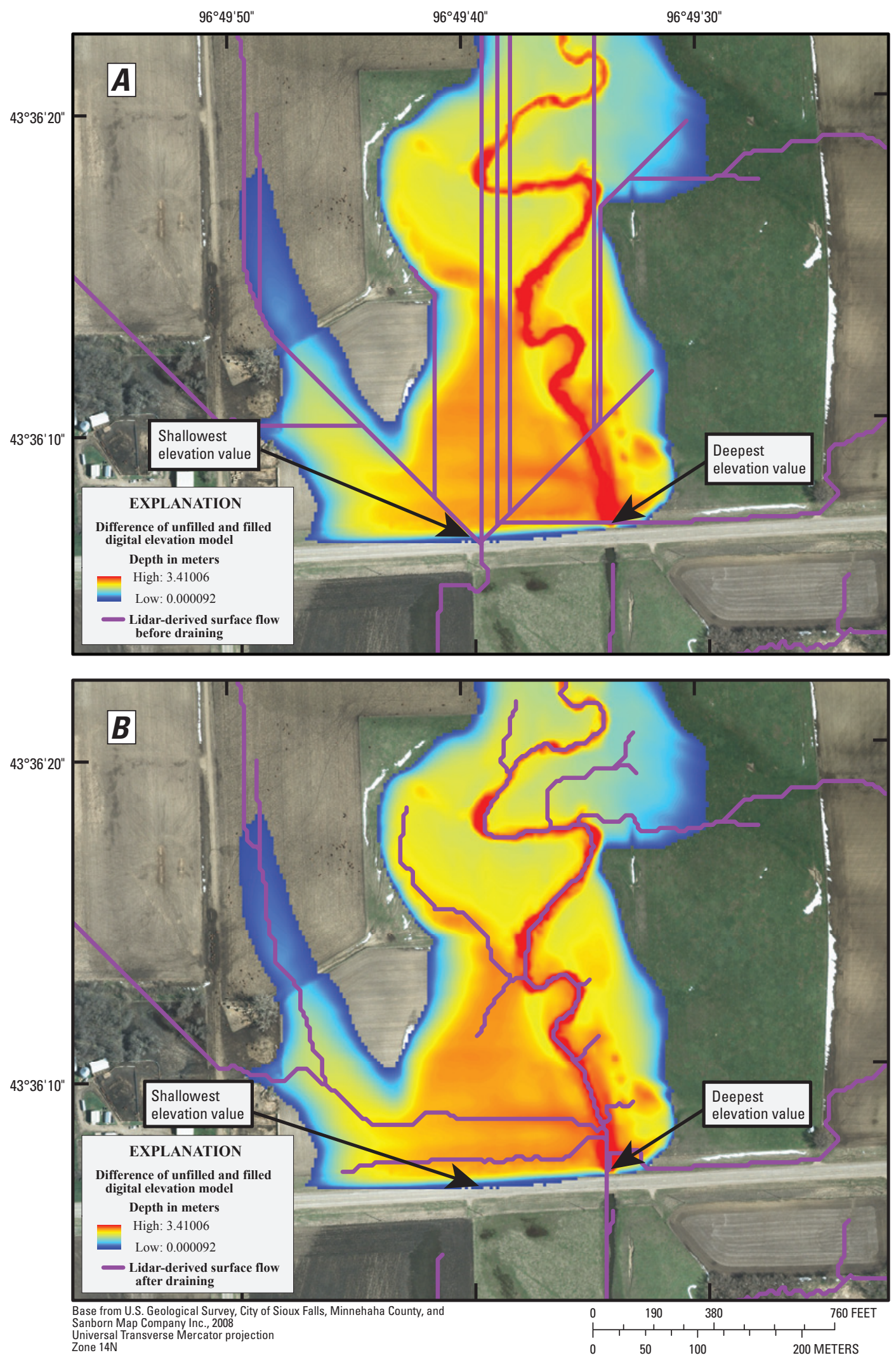

Horizonal coordinate information referenced to the North American Datum of 1983 (NAD 83)

Figure 1. Lidar-derived surface flow before $(A)$ and after $(B)$ selective draining of a difference grid depression that is overlain on aerial imagery of Minnehaha County, South Dakota. 

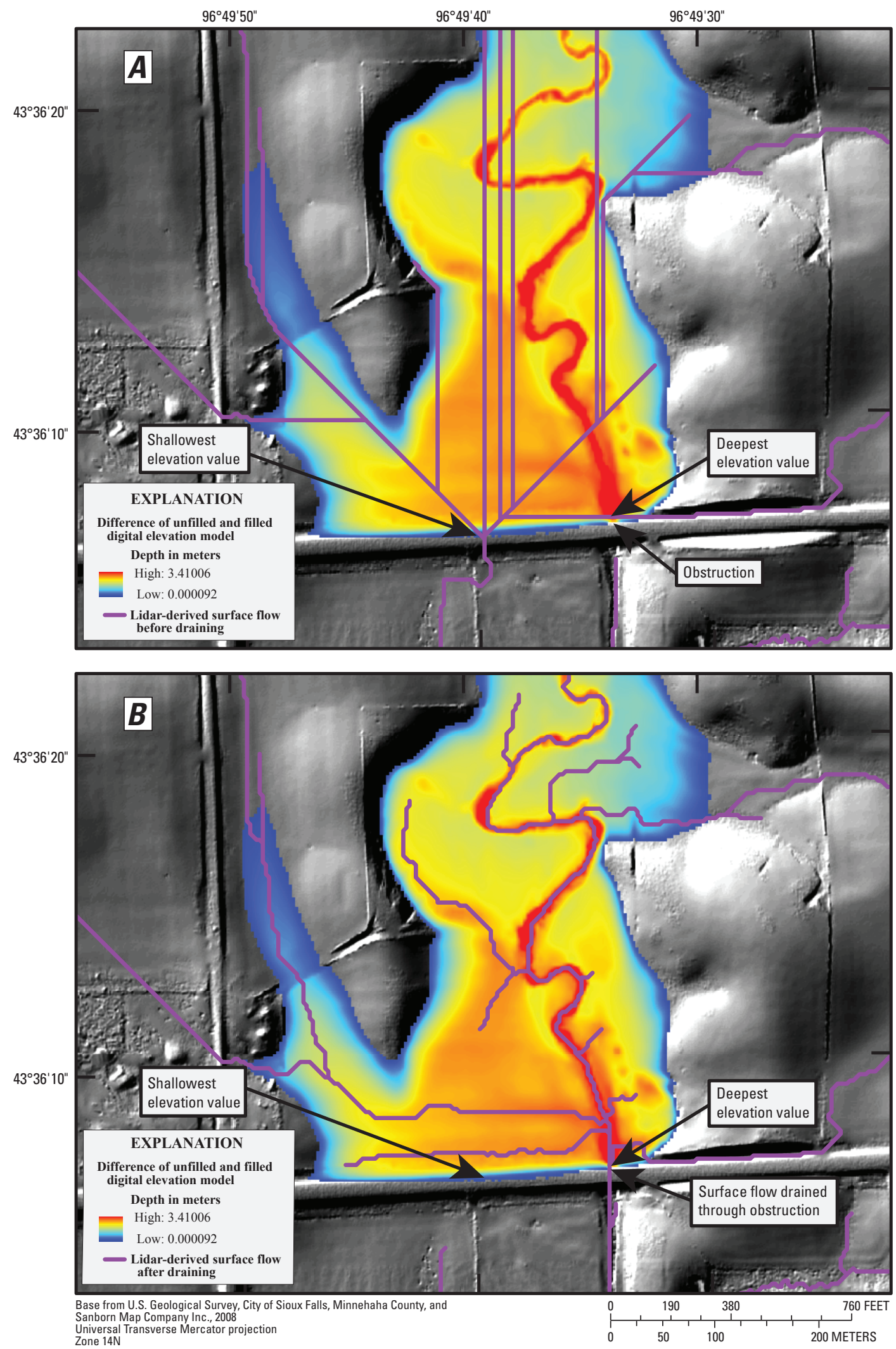

Horizonal coordinate information referenced to the North American Datum of 1983 (NAD 83)

Figure 2. Lidar-derived surface flow before $(A)$ and after $(B)$ selective draining of a difference grid depression that is overlain on 1-meter lidar-derived elevation data in Minnehaha County, South Dakota. 


\section{Study Area}

The U.S. Geological Survey (USGS) Sioux Falls West Quadrangle (U.S. Geological Survey, 1962), located in Minnehaha County in southeastern South Dakota, was selected to research and test the selective draining methods. The area consists of agricultural land interspersed and flanking the Sioux Falls metropolitan area (fig. 3). The physical landscape consists of rolling plains with watershed drainage flowing generally southeastward into the Big Sioux River, a tributary of the Missouri River. The gridded rectangular pattern of the rural transportation network and denser metropolitan street pattern is visible in the lidar elevation data (fig. 3). The denser network of metropolitan streets served as an example of a challenging elevation surface to extract continuous surface flow from lidar-derived DEMs.
Lidar point cloud data were collected with an airborne platform for Minnehaha County in May 2008 by Sanborn Map Company Inc. The data met the National Standard for Spatial Data Accuracy at 18.5 centimeter root mean square error (RMSE) on open bare terrain and 37.0 centimeter RMSE in obscured "vegetative" areas (Poppenga and others, 2009). The lidar vendor processed the data to bare earth elevation before the USGS incorporated the elevation data into the NED, the elevation layer of "The National Map" (http://www. nationalmap.gov).

\section{Selective Drainage Methods}

Spurious depressions in the DEM are identified and filled by raising the values of cells in depressions to the value of the

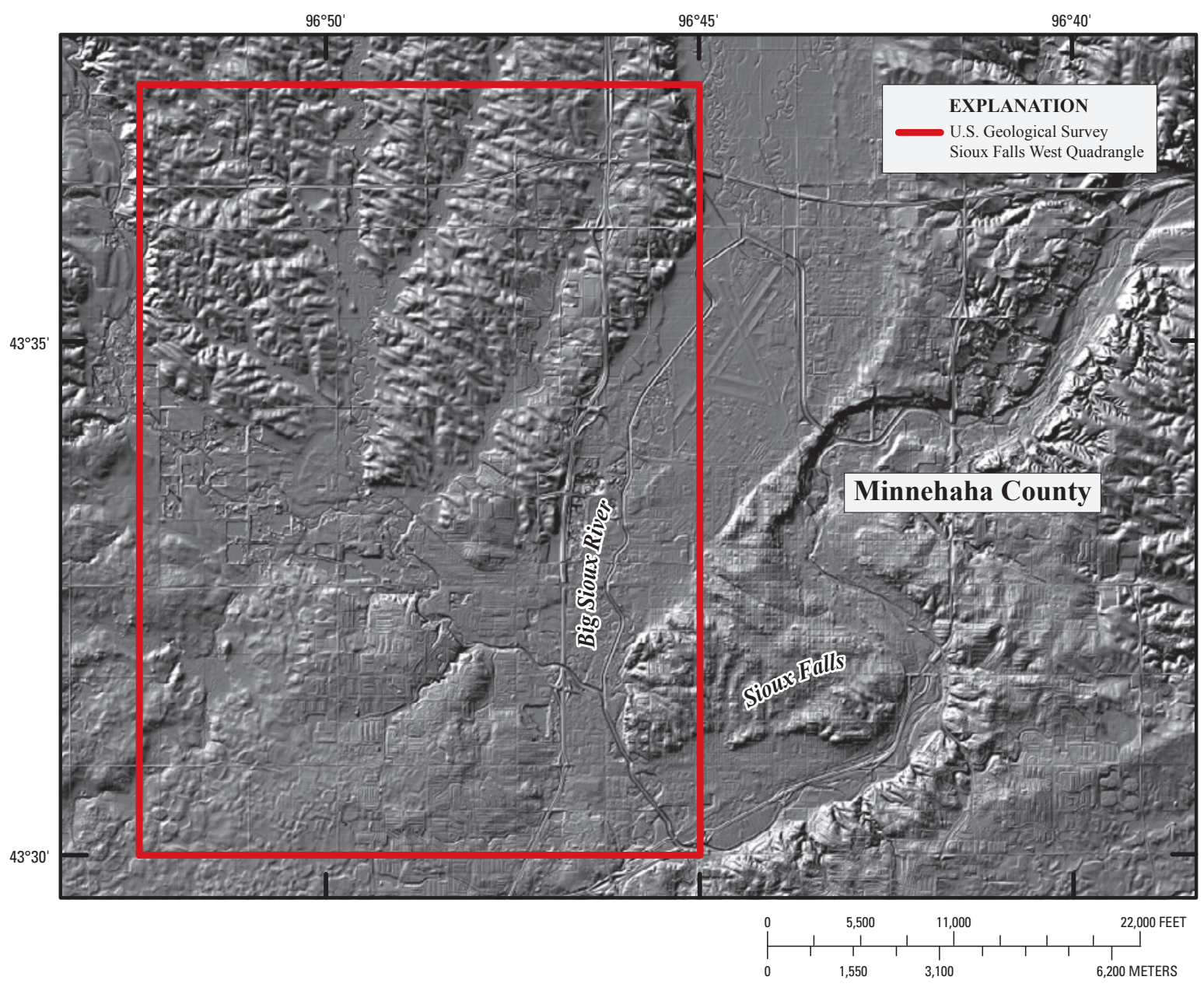

Figure 3. Research area located in the U.S. Geological Survey Sioux Falls West Quadrangle N4330—W9645/7.5 overlain on 1-meter lidar-derived elevation data in Minnehaha County, South Dakota. 
spill point of the depression using the standard filling techniques (Jenson and Domingue, 1988; Jenson, 1991) described previously. The output of the filling process is a new, depressionless DEM. The depressionless DEM is used in the second preprocessing step to compute flow direction representing the steepest down slope direction for each cell. The third conditioning step is the computation of the flow accumulation in which each cell receives a value equal to the number of cells that drain to it (Jenson, 1991) (fig. $4 A$ and $4 B$ ).

Because of the complexity of the lidar-derived DEM, extracting continuous surface flow using only the three-step hydrologic conditioning process can result in a drainage network that misrepresents the true flow on the landscape (fig. $4 B)$. For example, geographic features such as elevation data representing road base or grade overlying hydraulic structures (bridges or culverts) are more prominent in high-resolution elevation data. Consequently, these features become surface flow obstructions that cause depressions to form upstream from the structures. Additional processes are needed to derive a fully connected drainage network. To that end, semi-automated techniques and metrics were developed for classifying depressions to drain surface flow by cutting through the obstructions (fig. 4C).

The method for identifying and classifying depressions begins by subtracting the unfilled lidar DEM from the filled lidar DEM. The output is a mask, or "difference grid," containing depth values for all cells in each depression (figs. 1, 2, and $4 C$ ). The difference grid contains large numbers of small, insignificant depressions, many of which are interpolation artifacts of the DEM. Thus, the number of depressions that needs to be drained can be decreased by classifying depressions based upon parameters, such as area or depth. The depressions that meet all parameters are eligible for draining surface flow through obstructions. The depressions that are selectively classified and extracted from the lidar difference grid contain depth values that are important in identifying the location of surface flow obstructions, such as elevation data representing bridges or roads. In many cases, the deepest cell in a depression is the location of a surface flow obstruction and surface flow can be drained at that location (Poppenga and others, 2009) (figs. 1 and 2).

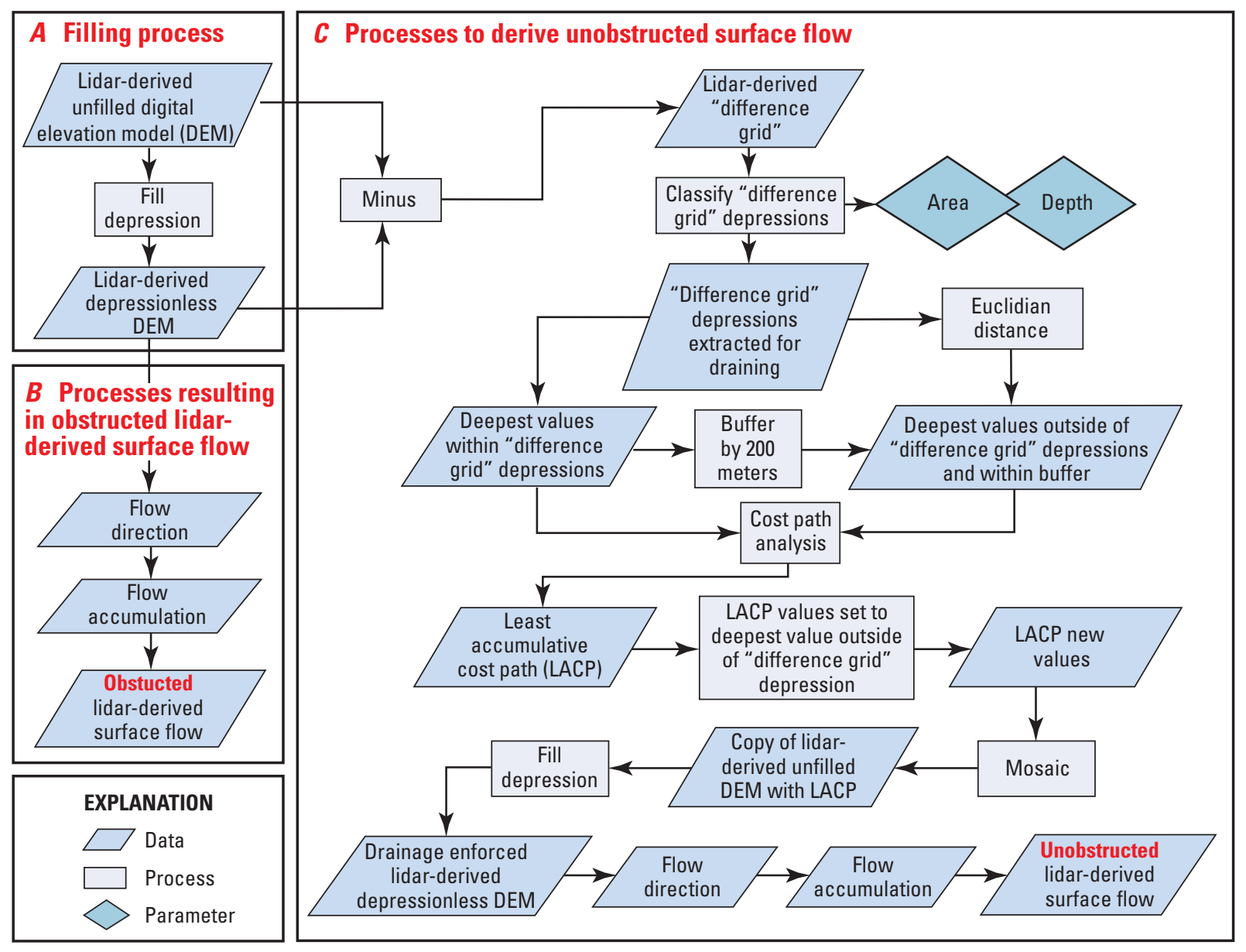

Figure 4. Selective drainage methods showing $(A)$ filling process to create a depressionless $D E M,(B)$ contributing area threshold processes that results in obstructed lidar-derived surface flow, and $(C)$ selective drainage methods that drains surface flow through obstructions to create a fully connected drainage network. 
The selective draining method (fig. $4 C$ ) for draining surface flow through an obstruction depends upon two variables: identification of the lowest elevation value in a depression that is upstream from the flow obstruction, and identification of nearest cells outside the depression with elevations lower than the lowest elevation inside the depression.

Each depression is evaluated independently to identify the deepest location or cell (source) within the depression. This cell is used as a starting location for delineating a path through the obstruction. Candidate target cells (destination) are locations outside the depression that have elevation values less than or equal to the lowest cell within the depression. A 200-meter buffer is used to limit the search distance. Euclidian distance and cost path functions are used to choose the closest of the candidate cells to delineate a path connecting the two cells (source and destination). To derive connected drainage, the elevation value of the lowest cell outside of the depression is used as the elevation values along the path connecting the two cells (source and destination). This path is the least accumulative cost path whereby a few elevation values are modified to allow a depression to properly drain at the location of a conduit.

The least accumulative cost path adjusted elevation values are incorporated into a copy of the unfilled lidar DEM, and the three-step hydrologic conditioning phase processes (filling, computing flow direction, and computing flow accumulation) are re-calculated with the drained elevation values (fig. 4C). By minimally modifying elevation values at conduit locations, surface flow drains through depressions, thereby creating a fully connected lidar-derived surface flow network. By draining surface flow through obstructions using these selective draining methods, the lidar-surface flow more closely resembles what is occurring on the landscape with minimal modifications to the DEM data.

\section{Identifying and Classifying Depressions}

Minnehaha County bare earth elevation data derived from lidar were used to produce 1-meter DEMs with a Universal Transverse Mercator Zone 14 projection and a North American Datum of 1983 horizontal datum. A shaded relief image of the 1-meter lidar-derived DEM is shown in figure 3. A buffered USGS Sioux Falls West Quadrangle DEM was extracted from the bare earth elevation data and filled to create a depressionless DEM. To identify and classify depressions, a difference grid was produced by subtracting the unfilled DEM from the depressionless (filled) DEM (fig. 4C).

In the study area, the difference grid depressions exceeded 60,000 polygons. Therefore, to efficiently extract continuous lidar-derived surface flow, the number of depressions was decreased to 227 polygons by classifying them based upon the following parameters:
- area greater than or equal to 1,000 square meters; and

- depth greater than or equal to 1 meter and greater than 0.5 standard deviation of the difference grid.

The depressions that met these parameters were used to drain surface flow through obstructions. Surface flow was drained through obstructions by calculating the least accumulated cost path for each obstructed area, and the breached elevation values were incorporated into a copy of the lidarderived DEM. Finally, the three-step hydrologic conditioning phase was re-calculated with the new lidar elevation values resulting in lidar-derived continuous surface flow (fig. $4 C$ ).

Lidar-derived elevation data present complex and challenging scenarios for generating continuous surface flow features. Nonetheless, the results of the selective draining methods provide fully integrated geospatial data that contain important information for research applications. The following paragraphs include examples of methods and technologies that are being refined and tested to enhance the use of lidar in deriving continuous surface flow features.

The value of the selective draining methods is the ability to automatically identify most surface flow obstructions by using the deepest cell(s) of difference grid depressions to drain surface flow through an obstruction. However, considering the hydrologic complexity of the surface of the earth, some depressions are actual closed drainage basins that do not contribute to downstream flow. Therefore, closed basins were identified by classifying them based on location and depth values of the deepest cells within the difference grid depressions. For example, in the Sioux Falls West Quadrangle, several of the filled depressions had a depth greater than 60 meters with their deepest cell(s) in their centroid. They were identified as operative Sioux Quartzite mines and were classified as closed drainage basins that were excluded from the selective draining methods (fig. 5).

Although there is value in identifying the deepest cells(s) of filled depressions, identification of the shallowest cell is important for determining where water would overflow in a flood. If a culvert or bridge could not accommodate the floodwaters, the surface flow would back up and spill out of the depression at the shallowest cell. In other words, in figures 1 and 2, the deepest cell or highest elevation value of the depression is indicative of a surface flow obstruction representing a culvert or bridge. If this conduit was blocked, the depression would become inundated and the surface flow would spill out of the depression at the shallowest cell or lowest elevation value (Poppenga and others, 2009). This is important geospatial information for land use planners, flood hazard management, or insurance entities interested in identifying geographic areas prone to risks of flooding. 

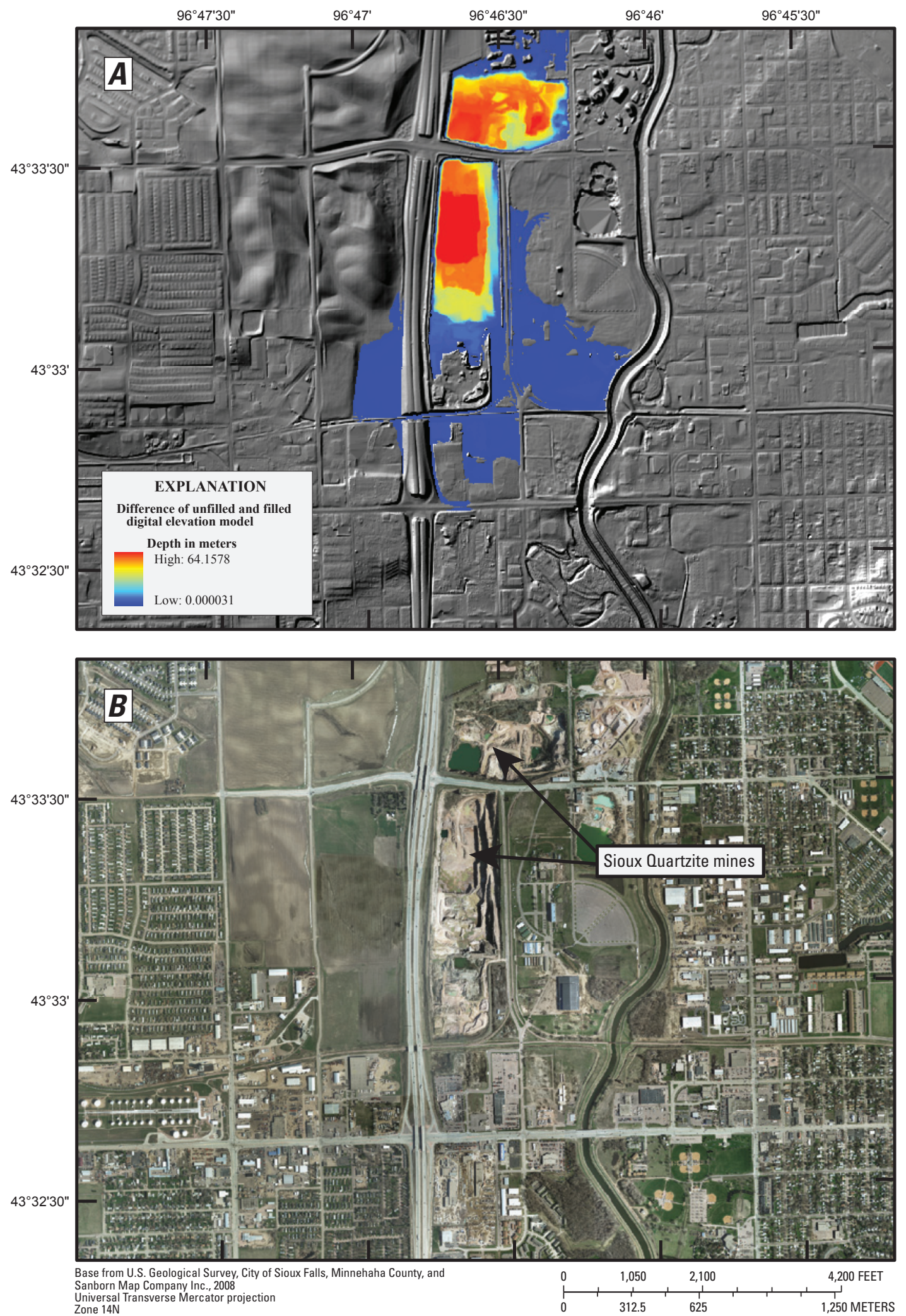

Horizonal coordinate information referenced to the North American Datum of 1983 (NAD 83)

Figure 5. Closed drainage basins identified as Sioux Quartzite mines that do not contribute to downstream flow with $(A)$ the difference grid depression depth at the deepest cell is 64.1578 meters, and $(B)$ aerial imagery of the Sioux Quartzite mines. 


\section{Discussion}

Lidar data, or point cloud returns, are an effective remote sensing technology capable of delivering highly accurate topographic surface representations (Stoker and others, 2005). However, lidar returns are sparsely recorded in areas of larger stream channels or water bodies because lidar laser pulses are not reflected by water. Because of the decreased point cloud return density, water surfaces in a lidar-derived gridded DEM typically inherit a triangulated irregular network (TIN), or tinning pattern (fig. 6). In the selective draining methods, the tinning pattern associated with water caused the surface flow to drain unevenly down the elevation slope. Although USGS specifications for lidar data acquisition and derivative products are in the process of being defined, additional research is needed to alleviate surface flow problems caused by voids over water in the lidar point cloud.

Even though selective draining methods are affected negatively by the absence of lidar returns over water surfaces, ongoing analysis of lidar voids indicates potential for thresholding and extracting potential water bodies (fig. 7) and double line streams from lidar return voids using density analysis and return intensity methods. This research could provide the capability to correct the tinning of water bodies in lidar-derived gridded elevation data so that the best available elevation data can be incorporated into the NED.

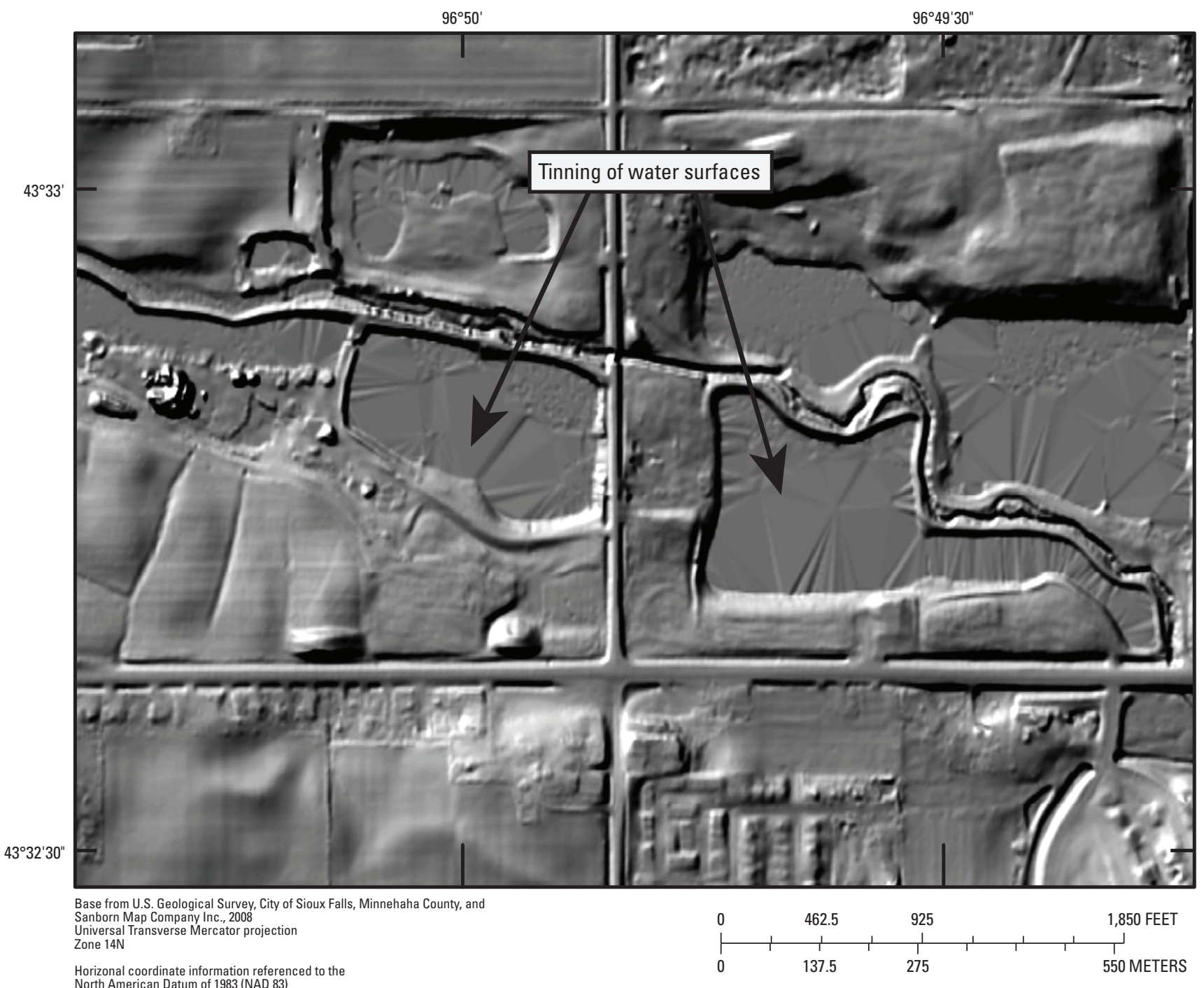

Figure 6. The tinning of water surfaces in the 1-meter lidar-derived elevation data. 


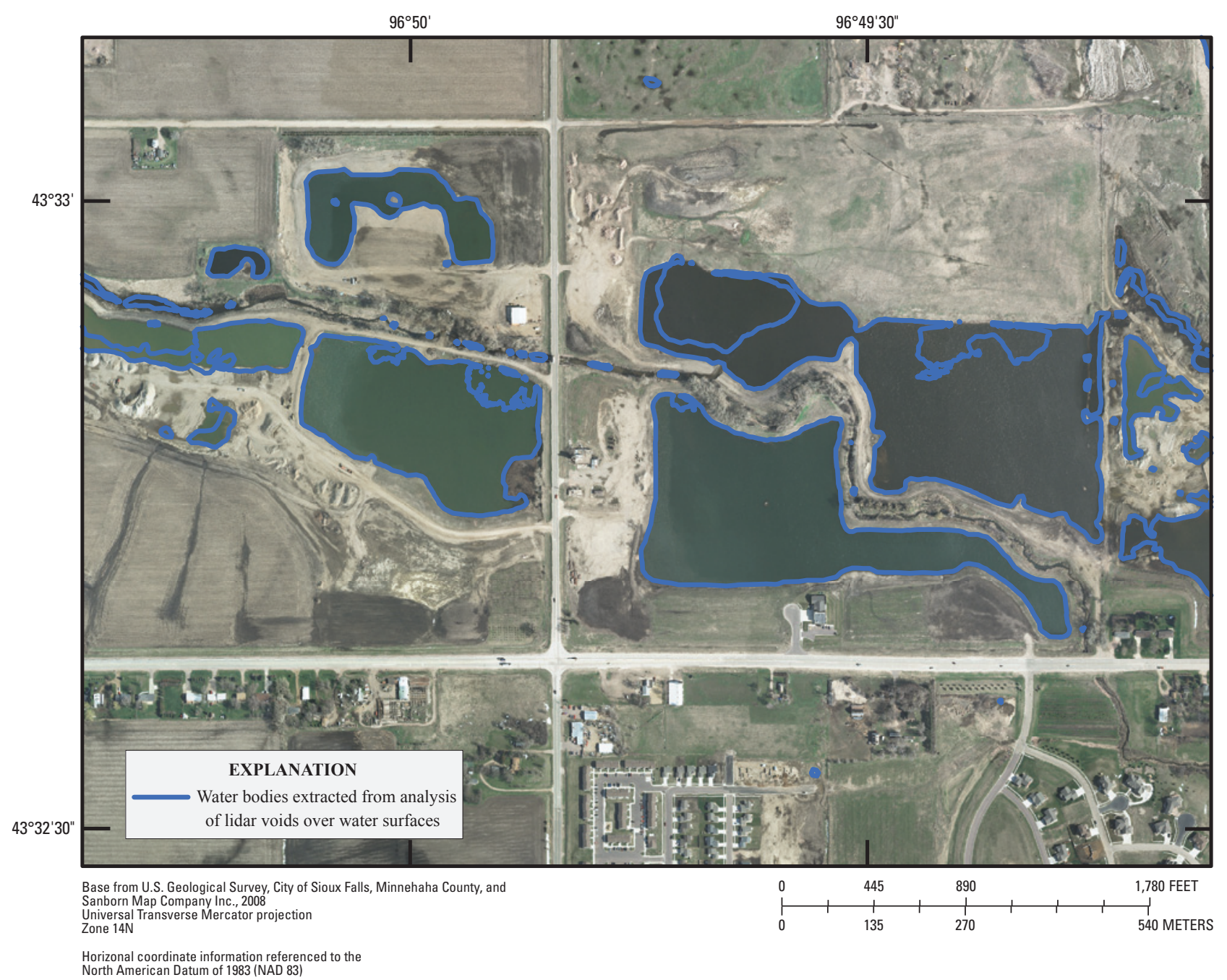

Figure 7. Water bodies extracted from the absence of lidar returns over water surfaces in 1-meter lidar point cloud data overlain on aerial imagery of Minnehaha County, South Dakota.

\section{Summary and Conclusion}

There is an increasing demand for continuous surface flow extracted from light detection and ranging (lidar)-derived bare earth digital elevation models (DEMs). Contributing area threshold models that previously have been used to extract continuous surface flow, or hydrologic derivatives, from coarser resolution elevation data $(30 \mathrm{~m})$ are no longer sufficient to extract continuous surface flow from lidar-derived DEMs because of the increased vertical accuracy of the finely detailed elevation surface. Therefore, the U.S. Geological Survey (USGS) has developed selective drainage methods to extract continuous surface flow from high-resolution lidar-derived DEMs. Because of the quality of the lidar data acquired in Minnehaha County in southeastern South Dakota, the USGS Sioux Falls West Quadrangle was selected to research and test the selective draining methods.
DEMs can be processed to extract a wealth of hydrologic information. Numerous methods have been developed to extract hydrologic data from coarser resolution elevation data, but the identification and filling of spurious depressions to derive continuous surface flow still remains a significant problem for most models. This problem intensifies when deriving continuous surface flow from lidar-derived DEMs because of the finely detailed complex elevation surface. Although the detail is valuable for incorporating the best available elevation data into the National Elevation Dataset (NED), extracting continuous surface flow from high-resolution DEMs presents challenges because obstructions, such as elevation data representing bridges or roads, are introduced.

In high-resolution elevation data, such as lidar, geographic features are more prominent; consequently, they cause impediments to extracting continuous surface flow. The USGS developed semi-automated methods to drain flow through 
obstructions by identifying and classifying depressions based on parameters. By classifying surface flow depressions, lidarderived feature extraction is enhanced by providing continuous surface flow that is consistently integrated with elevation and hydrographic and geographic features. This information is valuable for water resource managers who are dependent upon topographic and hydrologic features that traditionally have been derived from topographic maps, field surveys, or photographic interpretations.

As an enhancement to existing geospatial data, continuous surface flow features derived from lidar offer a remote sensing framework for improving the quality and currency of hydrologic data that are important for hydrologic modeling and water-resource management. As the demand for lidarderived continuous surface flow increases, lidar's integrative qualities are useful for hydrologic applications involving flood hazard mapping, flood inundation, and coastal erosion.

\section{Acknowledgments}

The contributions of the following individuals are gratefully acknowledged: Dean Gesch (USGS) for advice and encouragement; Gayla Evans (USGS), Karl Heidemann (USGS), Sandra Prince (SGT, Inc.), Jordan Menig (SGT, Inc.), Zheng Zhang (SGT, Inc.), and Mike Oimoen (SGT, Inc.) for lidar data collection, lidar processing, and National Elevation Dataset (NED) production. Also, thank you to the following for access to the Minnehaha County lidar data: the city of Sioux Falls, Minnehaha County, and Sanborn Map Company, Inc.

\section{References Cited}

Band, L.E., 1986, Topographic partition of watersheds with digital elevation models: Water Resources Research, v. 22, p. 15-24.

Band, L.E., 1999, Spatial hydrography and landforms, in Longley, P.A., and others, eds., Principles and technical issues: Geographical Information Systems: New York, Wiley, v. 1, p. 527-542.

Barber, C.P., and Shortridge, A.M., 2005, Lidar elevation data for surface hydrologic modeling-Resolution and representation issues: Cartography and Geographic Information Science, v. 32, p. 401-410.

Duke, G.D., Kienzle, S.W., Johnson, D.L., and Byrne, J.M., 2003, Improving overland flow routing by incorporating ancillary road data into digital elevation models: Journal of Spatial Hydrology, v. 3, p. 1-27.
Garbrecht, J., and Martz, L.W., 2000, Digital elevation model issues in water resources modeling, in Maidment, D., and Djokic, D., eds, Hydrologic and hydraulic modeling support with geographic information systems: Redlands, Calif., ESRI Press, p. 1-27.

Gesch, D.B., 1999, Chapter 31-The effects of DEM generalization methods on derived hydrologic features, in Lowell, Kim, and Annick Jaton, eds., Spatial accuracy assessmentLand information uncertainty in natural resources: Chelsea, Mich., Ann Arbor Press, p. 255-262.

Gesch, D.B., 2005, Analysis of multi-temporal geospatial data sets to assess the landscape effects of surface mining, in Barnhisel, R.I., ed., Proceedings, 22nd Annual National Conference of the American Society of Mining and Reclamation, Breckenridge, Colorado, June 19-23, 2005 (CDROM), ASMR, Lexington, Ky., p. 415-432.

Gesch, D.B., 2007, Chapter 4 - The National Elevation Dataset, in Maune, D.F., ed., Digital elevation model technologies and applications-The DEM users manual (2d ed.): Bethesda, Md., American Society for Photogrammetry and Remote Sensing, p. 99-118.

Gesch, D., Oimoen, M., Greenlee, S., Nelson, C., Steuck, M., and Tyler, D., 2002, The National Elevation Dataset: Photogrammetric Engineering \& Remote Sensing, v. 68, p. $5-11$.

Hutchinson, M.F., and Gallant, J.C., 1999, Representation of terrain, in Longley, P.A., and others, eds., Geographical information systems: Principles and Technical Issues $(2 \mathrm{~d}$ ed.): New York, John Wiley, p. 105-124.

Jenson, S.K., 1991, Applications of hydrologic information automatically extracted from digital elevation models: Hydrological Processes, v. 5, p. 31-44.

Jenson, S.K., and Domingue, J.O., 1988, Extracting topographic structure from digital elevation data for geographic information system analysis: Photogrammetric Engineering and Remote Sensing, v. 54, p. 1,593-1,600.

Kenny, F.M., Bates, S., and Matthews, B., 2001, Development of large-scale digital watershed covers for Ontario, in Proceedings of the 53rd Canadian Water Resources Association Conference, Saskatoon, Saskatchewan, Canada.

Kenny, F., Matthews, B., and Todd, K., 2008, Routing overland flow through sinks and flats in interpolated raster terrain surfaces: Computers \& Geosciences, v. 34, p. $1,417-1,430$.

Kost, J., and Kelly, G., 2001, Watershed delineation using the National Elevation Dataset and semiautomated techniques: Proceedings of the 21st ESRI User's Conference, July 9-13, 2001, San Diego, CD-ROM. 
Liu, X., Peterson, J., and Zhang, Z., 2005, High-resolution DEM generated from LiDAR data for water resource management, in Proceedings of International Congress on Modelling and Simulation 'MODSIM05', December 12-15, 2005, Melbourne, Australia, p. 1,402-1,408.

Mark, D.M., 1983, Automated detection of drainage networks for digital elevation models: Proceedings of Auto-Carta 6, v. 2, Ottawa, Ontario, Canada, p. 288-298.

Marks, D., Dozier, J., and Frew, J., 1984, Automated basin delineation from digital elevation data: Geoprocessing, v. 2, p. 299-311.

Martz, L.W., and Garbrecht, J., 1993, Automated extraction of drainage network and watershed data from digital elevation models: Water Resources Bulletin, v. 29, p. 901-908.

Martz, L.W., and Garbrecht, J., 1999, An outlet breaching algorithm for the treatment of closed depressions in a raster DEM: Computers \& Geosciences, v. 25, p. 835-844.

Matthews, B., and Kuyvenhoven, R., 2002, The WRIP toolbox manual: Peterborough, Ontario, Canada, Ontario Ministry of Natural Resources, $31 \mathrm{p}$.

Moore, I.D., Grayson, R.B., and Ladson, A.R., 1991, Digital terrain modeling-A review of hydrological, geomorphological, and biological applications: Hydrological Processes, v. 5 , p. 3-30.

Moore, I.D., Turner, K., Wilson, J., Jenson, S., and Band, L., 1993, GIS and land-surface-subsurface modeling, in Goodchild, M., and others, eds., Environmental modeling with GIS: New York, Oxford University Press, p. 196-230.

O'Callaghan, J.F., and Mark, D.M., 1984, The extraction of drainage networks from digital elevation data: Computer Vision, Graphics and Image Processing, v. 28, p. 323-344.

Poppenga, S.K., and Worstell, B.B., 2008, Elevation-derived watershed basins and characteristics for major rivers of the conterminous United States: U.S. Geological Survey Scientific Investigations Report 2008-5153, 27 p.

Poppenga, S.K., Worstell, B.B., Stoker, J.M., and Greenlee, S.K., 2009, Comparison of surface flow features from lidar-derived digital elevation models with historical elevation and hydrography data for Minnehaha County, South Dakota: U.S. Geological Survey Scientific Investigations Report 2009-5065, 24 p.

Snyder, N.P., 2009, Studying stream morphology with airborne laser elevation data: Eos, Transactions, American Geophysical Union, v. 90, p. 45-46.

Stoker, J.M., 2009, Volumetric visualization of multiple-return lidar data: Using voxels: Photogrammetric Engineering and Remote Sensing, v. 75, p. 109-112.
Stoker, J.M., Greenlee, S.K., Gesch, D.B., Hubl, E.J., and Axmann, R.N., 2005, Collection and analysis of high-resolution elevation data for the Lincoln lidar project, Lincoln, Nebraska, 2004: U.S. Geological Survey Open-File Report 2005-1049, $37 \mathrm{p}$.

Stoker, J.M., Greenlee, S.K., Gesch, D.B., and Menig, J.C., 2006, CLICK - The new USGS Center for Lidar Information Coordination and Knowledge: Photogrammetric Engineering \& Remote Sensing, v. 72, p. 613-616.

Stoker, J., Harding, D., and Parrish, J., 2008, The need for a National Lidar Dataset: Photogrammetric Engineering \& Remote Sensing, v. 74, p. 1,066-1,068.

U.S. Geological Survey, 1962, Sioux Falls West Quadrangle: U.S. Geological Survey Quadrangle Map N4330W9645/7.5, scale 1:24,000.

Wang, L., and Liu, H., 2006, An efficient method for identifying and filling surface depressions in digital elevation models for hydrologic analysis and modeling: International Journal of Geographical Information Science, v. 20, p. 193-213.

Wolock, D.M., and McCabe, G.J., 2000, Differences in topographic characteristics computed from 100 and $1000 \mathrm{~m}$ resolution digital elevation data: Hydrological Processes, v. 14 , p. $987-1,002$.

Zhang, W., and Montgomery, D.R., 1994, Digital elevation model grid size, landscape representation, and hydrologic simulations: Water Resource Research, v. 30, p. 1,0191,028 .

Publishing support provided by:

Rolla Publishing Service Center

For more information concerning this publication, contact:

U.S. Geological Survey Earth Resources Observation and Science (EROS) Center

47914 252nd Street

Sioux Falls, South Dakota 57198

(605) 594-6151

Or visit the EROS Center Web site at:

World Wide Web: http://eros.usgs.gov/ 



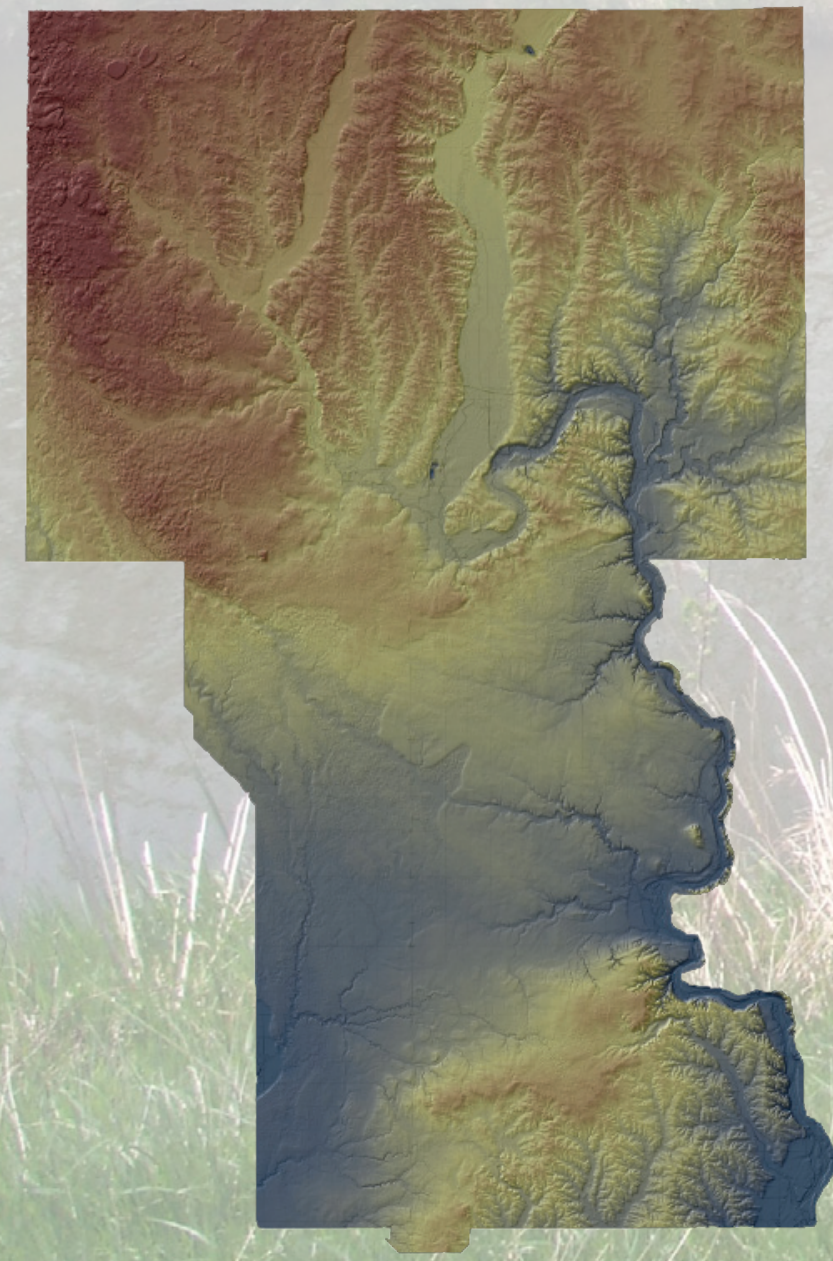

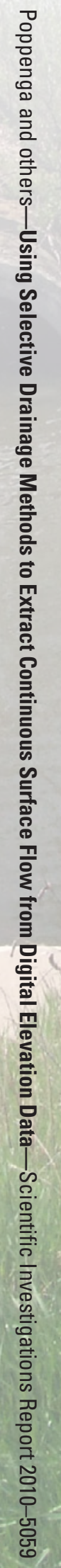

